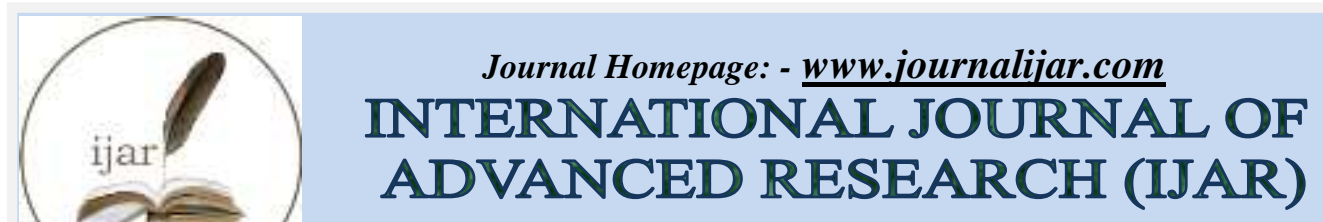

Article DOI: $10.21474 / \mathrm{IJAR} 01 / 7595$

DOI URL: http://dx.doi.org/10.21474/IJAR01/7595

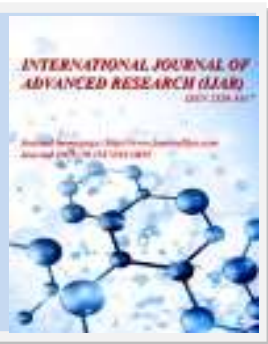

RESEARCH ARTICLE

\title{
CHARACTERISTICS AND DROPOUT RATE AMONG RESIDENTS IN A TERTIARY HOSPITAL IN JEDDAH, SAUDI ARABIA: A CROSS-SECTIONAL STUDY.
}

\author{
Rayan Hejazi, Majed Almuraee, Alwaleed Alyami, Albaraa Alghamdi and Ali H Al-Yami. \\ 6080 Almuhammadiyah, Jeddah, 23624, Saudi Arabia.
}

\section{Manuscript Info}

Abstract

Manuscript History

Received: 20 June 2018

Final Accepted: 22 July 2018

Published: August 2018

Copy Right, IJAR, 2018,. All rights reserved.

\section{Introduction:-}

The residents' interest toward the surgical fields has dropped significantly in the past few years. The attrition, resigning or dropout of, residents in surgical departments happens mostly in early years of training and most of them join other programs. Most dropouts are in the first year of training. The attrition rate in a study done by Yeo $\mathrm{H}$, et al was $19.5 \%$. (Yeo et al. 2010) The females are more toward leaving the general surgery training program than men. Most common cause of attrition is seeking a better quality of life and family reasons. (Morris et al. 2003) There will be a burden on the health care system caused by the decreased interest toward surgery programs and the loss of residents after they join those surgery programs. (Dodson \& Webb 2005) Residency programs cannot replace those who left the program easily. (Aufses et al. 1998) Even non-surgical fields had the problem of residents leaving the training. Directors of family practice residency training programs reported a dropout rate of $18.5 \%$ for international graduates, compared with $7.8 \%$ for U.S. graduates $(\mathrm{P}<.0001)$. (Laufenburg et al. 1994)

\section{Study question:-}

Based on literature search, we hypothesized that female gender could be associated with increased tendency toward dropout of surgical specialty in our local residency training programs in National guard health affairs in the city of Jeddah, Saudi Arabia

\section{Aim and objectives:-}

The study aimed to assess if gender is a factor associated with increased tendency to dropout of residency training. Identify the attrition rates among residents in different surgical and non-surgical residency programs in the King Abdul Aziz medical city, Jeddah, Saudi Arabia and the possible causes of dropout.

\section{Methodology:-}

This is a cross-sectional. We did a survey targeting all residents training in different training programs in KAMC, Jeddah, Saudi Arabia during the year of 2017. (See appendix 1) Study subjects participated voluntarily. An informed consent form was provided. Our survey included demographic data, information about the current specialty training program, history of enrolment in a previous residency programs, and causes of dropout of the previous program, if present. Tests used for Data Analysis The variables are assessed for normal distribution. For data that does not fulfill the criteria of parametric tests, nonparametric tests will be used accordingly. Mean and standard deviation was used to describe continuous variables. Frequencies and percentages for categorical variables. 
To determine significance of the difference between two categorical variables, chi square test was used. Student ttest was used to compare the means between two groups. The data was entered, managed and analyzed using GNU PSPP 0.10 public license version 3, 29 June 2007.

\section{Results:-}

Out of the 176 resident we interviewed (see table 1) only seven had a history of changing their residency training specialty, 3.9\%. 78 residents, $44 \%$, where in surgical specialties while $96,54 \%$, where in medical specialties. The surgical to medical dropout ratio was 4:2. Six out of seven, $86 \%$, of residents who changed their residency went to a non-surgical specialty. Most common causes of changing specialty were due to personal reasons (43\%), followed by excessive workload (29\%), the seniors' behavior (14\%) and for seeking an academic position (14\%).

Table 1:- This table shows the characteristics of residents in overall. We used the median and interquartile range to describe the data because it was skewed.

\begin{tabular}{|c|c|c|c|c|}
\hline Variable & Median & $\begin{array}{l}\text { Interquartile } \\
\text { range }\end{array}$ & \begin{tabular}{|l|} 
Lower \\
quartile \\
\end{tabular} & \begin{tabular}{|l|} 
Upper \\
quartile
\end{tabular} \\
\hline Age in years & 27 & 2 & 26 & 28 \\
\hline GPA in $\%$ & 84 & 13 & 76 & 89 \\
\hline Academic year & 2 & 2 & 1 & 3 \\
\hline Residents in the same academic year & 10 & 12 & 6 & 18 \\
\hline Monthly oncalls & 5 & 3 & 3 & 6 \\
\hline Percieved biological hazard out of 10 & 6 & 4 & 4 & 8 \\
\hline Percieved radiation hazard out of 10 & 3 & 6 & 1 & 7 \\
\hline
\end{tabular}

The residents who were in a surgical specialty had more on-call shifts and scored higher in the scale of radiation risk compared to non-surgical residents (t-test showed $\mathrm{P}$ values of $<0.05$ ). (See Table 2 ).

Table 2:- independent t-test results of testing difference between means. It is comparing medical versus surgical specialties. We can appreciate a significant difference between "Monthly on-calls" and "Radiation risk".

\begin{tabular}{|l|r|r|r|r|r|}
\hline Levene's Test for Equality of Variances & \multicolumn{3}{|c|}{ t-test for Equality of Means } \\
\hline & $\mathrm{F}$ & Sig. & $\mathrm{t}$ & $\mathrm{df}$ & Sig. (2-tailed) \\
\hline Monthly On-calls & 7,81 & 0,006 & $2,27-$ & 171 & 0,024 \\
\hline & & & $2,43-$ & 133,87 & 0,016 \\
\hline Radiation risk & 15,34 & & $3,54-$ & 171 & 0,001 \\
\hline & & & $3,46-$ & 144,7 & 0,001 \\
\hline
\end{tabular}

There was no gender association with the tendency toward changing residency training program. $(\mathrm{P}$ value $=0.381)$. Therefore, we failed to reject the null hypothesis. (See Table 3)

Table 3:- Pearson chi-square testing association between "gender" and "dropout". The result is not significant. P value is more than 0.05 . There is no difference between genders.

\begin{tabular}{|c|c|c|c|c|c|}
\hline Statistic & Value & $\mathrm{df}$ & Asymp. Sig. (2-tailed) & Exact Sig. (2-tailed) & Exact Sig. (1-tailed) \\
\hline \begin{tabular}{|l} 
Pearson Chi- \\
Square \\
\end{tabular} & 0,77 & 1 & 然 & & \\
\hline \begin{tabular}{|l|} 
Likelihood \\
Ratio \\
\end{tabular} & 0,8 & 1 & 0,371 & & \\
\hline \begin{tabular}{|l} 
Fisher's \\
Exact Test
\end{tabular} & & & & 0,462 & 0,318 \\
\hline
\end{tabular}

In the study done in USA, post-graduates-year 1 residents attrition was 154 out of 1409, 10.9\%. Most of them, $80.5 \%$ where transfer attrition not termination attrition. The transfer attrition rate is $8.8 \%$.

\section{Discussion:-}

The percentage of residents leaving residency training programs was is relatively low. We notice that most residents who had transferred went to non-surgical specialties. Non-response bias may have had some influence on the estimated dropout rate. Surgical specialties have more on-call shifts and radiation exposure., both are forms of stress. The demand on surgeons is causing them to burnout as the excessive workload was one of the top reasons of attrition. In contrary to the published data about female gender and the predisposition to having attrition, we could not detect a significant difference between males and females. This issue of residents not continuing in surgical residency training remains as an existing issue locally and worldwide.

\section{Limitations:-}

We did not consider termination attrition but only considered the transfer attrition. However, we except the effect to be minimal. Since most of attritions are attributed to transfer attrition not termination attrition. The response rate was around $50 \%$. Therefore, non-response bias may exist. 


\section{Recommendations:-}

Efforts should be applied to improve the selection of residents and to lessen the attrition to the minimum. Meetings and reflection and feedback sessions should take place where leaders meet the residents and discuss their personal issues and try to solve them.

\section{Acknowledgement:-}

We thank everyone who participated in the study and those who helped us through the processes of the research. We thank our supervisors for their time and efforts. Special thanks to Dr. Faisal Farahat for his valuable support in this research.

\section{References:-}

1. Aufses, A.H., Slater, G.I. \& Hollier, L.H., 1998. The nature and fate of categorical surgical residents who "drop out." American Journal of Surgery, 175(3), pp.236-239.

2. Dodson, T.F. \& Webb, A.L.B., 2005. Why do residents leave general surgery? The hidden problem in today's programs. In Current Surgery. pp. 128-131.

3. Laufenburg, H.F., Turkal, N.W. \& Baumgardner, D.J., 1994. Resident attrition from family practice residencies: United States versus international medical graduates. Family Medicine, 26(10), pp.614-617.

4. Morris, J.B., Leibrandt, T.J. \& Rhodes, R.S., 2003. Voluntary changes in surgery career paths: A survey of the program directors in surgery. Journal of the American College of Surgeons, 196(4), pp.611-616.

5. Yeo, H. et al., 2010. A National Study of Attrition in General Surgery Training Which Residents Leave and Where Do They Go? Ann Surg, 252, pp.529-536.

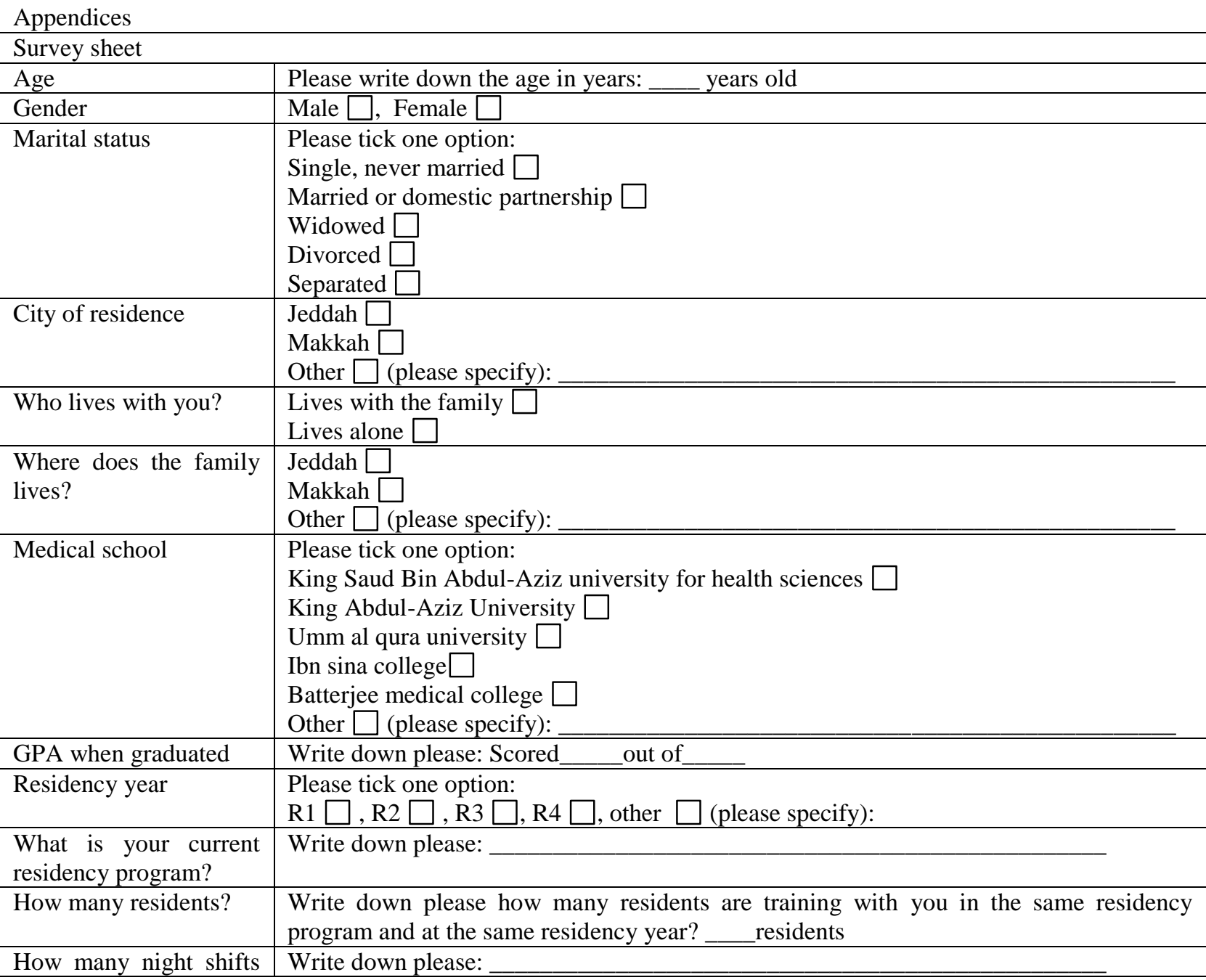




\begin{tabular}{|c|c|}
\hline last month? & \\
\hline $\begin{array}{l}\text { Biological risk e.g. you } \\
\text { risk of infection (as a } \\
\text { healthcare provider) }\end{array}$ & Please make a mark representing your risk on this scale: \\
\hline Radiation risk & 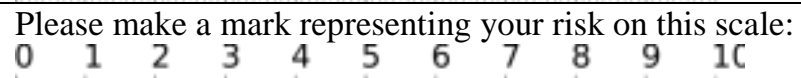 \\
\hline $\begin{array}{l}\text { Have you changed your } \\
\text { residency ever }\end{array}$ & $\begin{array}{l}\text { Please tick one option: } \\
\text { Yes } \square \text {, No } \square\end{array}$ \\
\hline $\begin{array}{l}\text { What was your previous } \\
\text { residency program? } \\
\text { (only if answered YES) }\end{array}$ & Please specify: \\
\hline $\begin{array}{l}\text { What was the reason? } \\
\text { (only if answered YES) }\end{array}$ & $\begin{array}{l}\text { Personal reasons } \square \\
\text { The behavior of faculty or senior residents } \square \\
\text { Excess workload } \square \\
\text { Other } \square \text { (please specify): }\end{array}$ \\
\hline
\end{tabular}

Appendix 1: The survey for residents in King Abdul-Aziz Medical city - Jeddah, Saudi Arabia 